\title{
Figures
}

\section{Stichographic Layout in the Dead Sea Psalms Scrolls: Observations on its Development and its Potential}

Fig. 1 Prose-layout in 11Q5, Col XXIII,6-12. Courtesy of The Leon Levy Dead Sea Scrolls Digital Library; Israel Antiquities Authority, photo: Shai Halevi — 17

Fig. 2 A column with two separate stichs: Mas 1e, Col ii and iii. Courtesy of The Leon Levy Dead Sea Scrolls Digital Library; Israel Antiquities Authority, photo: Shai Halevi $2 \mathbf{2 0}$

\section{Writing the Qur'ān Between the Lines: Marginal and Interlinear Notes in Selected Qur’ān Fragments from the Museum of Islamic Art, Qatar}

Fig. 1 Bifolio MIA. 67.2007.1. With kind permission of the museum of Islamic Art, Doha, Qatar 56

Fig. 2 MIA 2013.16. Folio 8.v. With kind permission of the museum of Islamic Art, Doha, Qatar -57

Fig. 3 Detail of marginal reference sign. MIA 2013.16 Folio 8.v. With kind permission of the Museum of Islamic Art, Doha, Qatar — 58

\section{From Scroll to Codex: Dynamics of Text Layout Transformation in the Hebrew Bible}

Fig. 1 Layout 1: A half brick over a half brick, and a whole brick over a whole brick — $\mathbf{9 6}$

Fig. 2 Layout 2: A half brick over a whole brick, and a whole brick over a half brick $\longrightarrow \mathbf{9 6}$

Fig. 3 Layout 3: Divided symmetrically in two parts - $\mathbf{9 8}$

Fig. 4 Layout 4: Layout of The Song at the Sea as described by Maimonides -100

Fig. 5 Layout of The Song at the Sea; LBP: Line before the poem; LAP: Line after the poem 104

Fig. 6 Paris, BnF, Hébreu 29, fol. 50r. With permission of the Bibliothèque nationale de France - 106

Fig. 7 Paris, BnF, Hébreu 24, fol. 37v. With permission of the Bibliothèque nationale de France -107

Fig. 8 Paris, BnF, Hébreu 28, fol. 37v. With permission of the Bibliothèque nationale de France - 108

Fig. 9 MS Paris, BnF, Hébreu 19, fol. 49r. With permission of the Bibliothèque nationale de France - 109

Fig. 10 MS Paris, BnF, Hébreu 8, fol. 75v. With permission of the Bibliothèque nationale de France - 111 


\section{Memory, Performance, and Change: The Psalms' Layout in Late Medieval and Early Modern Bibles}

Fig. 1 Cantate Domino - initial to Psalm 110/11 in the de Brailes Bible. Oxford, Bodleian Library, MS Lat. Bib. E. 7, fol. 191v. By permission of The Bodleian Library, University of Oxford - 123

Fig. 2 Late Medieval Bible Layout - Opening of Genesis, Edinburgh University Library MS 2, fols $3 v$-4r. Edinburgh University Library Special Collections — 124

Fig. 3 Psalm layout (detail); Oxford, Bodleian Library MS Bodl. 959. By permission of The Bodleian Library, University of Oxford - 128

Fig. 4 Wycliffite Psalter (British Library MS Yates Thompson 52, fol. 96v). () The British Library Board - $\mathbf{1 3 0}$

Fig. 5 Great Bible Psalms (The Byble in Englyshe [...] (London: Rychard Grafton and Edward Whitchurch, April 1539), pt 3 fol. 2v. Edinburgh University Library Special Collections - 137

Fig. 6 Grafton 1535 Psalms (The Bible in Englishe [...] (London: Richard Grafton, 1553), fols $188 \mathrm{v}-189 \mathrm{r})$. Reproduced by kind permission of the Syndics of Cambridge University Library - 140

Fig. 7 Geneva Bible Psalms (The Bible and Holy Scriptures [...] (Geneva: Rouland Hall, 1560), fol. 235v). Edinburgh University Library Special Collections - 142

Fig. 8 Bishops' Bible Psalms (The. holie. Bible [London: Richarde lugge, 1568], pt 3 p.3). Edinburgh University Library Special Collections — 144

Fig. 9 Bishops'1572 Psalms (The. holie. Bible [London: Richarde lugge, 1572], pt 3 p.3). Edinburgh University Library Special Collections — 145

\section{Be Your Own Scribe: Bible Journalling and the New Illuminators of the Densely-Printed Page}

Fig. 1 Carol Belleau: Deut 11:11-14. With kind permission of the artist — 167

Fig. 2 Salomé Vleeming, Psalm 112:4. With kind permission of the artist - 171

Fig. 3 Salomé Vleeming, Psalm 112:4, detail of lettering. With kind permission of the artist 172

Fig. 4 Sumayah Hassan, A page of a Qur'an journal featuring Ayah 28 from Surah 21. With kind permission of the artist -176

\section{Monks, Manuscripts, Muhammad, and Digital Editions of the New Testament}

Fig. 1 GA 2027 (Paris, BnF, gr. 491), Comment on Rev 13:18 (289r). With permission of the Bibliothèque nationale de France - 190

Fig. 2 GA 1732 (Athos, Lavra, A 91) comment on Rev 13:18 (detail, lower margin). Public Domain: Library of Congress Collection of Manuscripts from the Monasteries of Mt. Athos -191 
Fig. 3 GA 2073 (Athos, Iviron, 273), Comment on Rev 13:18 (73v). Public Domain: Library of Congress Collection of Manuscripts from the Monasteries of Mt. Athos -194

Fig. 4 GA 051 (Athos, Pantokratoros 44) comment on Rev 13:18 (15r). Public Domain: Library of Congress Collection of Manuscripts from the Monasteries of Mt. Athos - 196

\section{The Qur'ānic Text from Manuscript to Digital Form: Metalinguistic Markup of Scribes and Editors}

Fig. 1 Bare consonantal skeleton with homograph base letters: Arabic MS 11(688) f.23r, detail. John Rylands Library, The University of Manchester. Copyright of the University of Manchester. Layer extracted by Alba Fedeli — 226

Fig. 2 Bare consonantal skeleton with explicit reading of possible homographs: Arabic MS 11(688) f.23r, detail. John Rylands Library, The University of Manchester. Copyright of the University of Manchester. Layer extracted by Alba Fedeli - 226

Fig. 3 Red vowel-dot level (tuhrağūna): Arabic MS 11(688) f.23r, detail. John Rylands Library, The University of Manchester. Copyright of the University of Manchester. Layer extracted by Alba Fedeli — 226

Fig. 4 Green vowel-dot level (taḩruğūna): Arabic MS 11(688) f.23r, detail. John Rylands Library, The University of Manchester. Copyright of the University of Manchester. Layer extracted by Alba Fedeli $\longrightarrow 227$

Fig. 5 Red and green vowel-dot levels: Arabic MS 11(688) f.23r, detail. John Rylands Library, The University of Manchester. Copyright of the University of Manchester - 227 
